\title{
Understanding the crosstalk of molecular factors and signaling pathways reveals novel biomarkers of cisplatin resistance in testicular germ cell tumors
}

\author{
Minireview
}

J. ROSKA ${ }^{1}$, D. JURKOVICOVA ${ }^{1,2, *}$

${ }^{1}$ Biomedical Research Center, Cancer Research Institute, Department of Genetics, Slovak Academy of Sciences, Dubravska cesta 9, 84505 Bratislava, Slovakia; ${ }^{2}$ KRD molecular technologies s.r.o, Ruzinovska 3, 84201 Bratislava, Slovakia

${ }^{*}$ Correspondence: dana.jurkovicova@savba.sk

Received March 18, 2019 / Accepted July 3, 2019

\begin{abstract}
Testicular germ cell tumors (TGCTs) mostly affect young men, but fortunately belong to well curable solid tumors. Today, different treatment strategies are applied reaching excellent outcomes, and introduction of alternative approach of patient active surveillance or adjuvant chemotherapy after orchiectomy decreases number of unnecessary toxic treatments of young patients. Also for relapsing patients, salvage therapy offers high survival rates. However, small percentages of affected young men do not respond to conventional therapy regimen due to intrinsic or acquired therapy resistance. For closely watching of patients during active surveillance, patients' stratification due to their prognosis, detection of therapy resistance and early relapse before treatment initiation, reliable molecular biomarkers and diagnostic tools replacing conventional approaches are still needed. Complex understanding of disease development and progression as well as mechanisms of chemoresistance and their epigenetic or chronobiological regulation pre-requisite successful search for such novel biomarkers. In this review, we aimed to highlight the importance of crosstalk of different regulatory mechanisms and their key players affecting treatment response, and focus on their potential as novel molecular biomarkers and/or druggable targets.
\end{abstract}

Key words: testicular germ cell tumor, cisplatin resistance, DNA damage and repair, epigenetics, hypoxia, chronobiology

Testicular germ cell tumors (TGCTs) are the most common form of malignant solid tumors in young adult men and their incidence is continuously increasing. In Europe, the most affected individuals are young Caucasians, mostly from Scandinavian countries, and increasing trends are still observed [1]. About 23,000 new cases are predicted to occur in Europe by 2025 [2]. In the United States, the highest increase in the incidence of TGCT was observed in Hispanic population [3]. Racial differences in predisposition to TGCT have been identified; white men show the highest risk, while African or Asian men have lower risk of disease development [4].

TGCTs account for $\sim 98 \%$ of all testicular malignancies exerting wide histological heterogeneity, mostly attributed to pluripotency of the originating germ cell line [5]. TGCTs derived from arrested, improperly developing fetal gonocytes accumulate oncogenic mutations, become germ cell neoplasia in situ (GCNIS) in childhood and adolescence, and can turn to invasive TGCT in the young adults [6]. Based on a histological type, TGCTs are generally classified into seminoma (SE) and non-seminomatous tumors (NSTs) [5, 7]. SEs are homogenous and develop most frequently at the age of 35-39 years, while NSTs at younger age of 25-29 years. NSTs are usually heterogeneous due to dysregulated differentiation and generally more aggressive, containing different histological tumor components. The undifferentiated embryonal carcinoma (EC) cells show pluripotential stem cell character and can differentiate into either extra-embryonal tissues like choriocarcinoma (CC), yolk sac tumor (YST) or somatic derivatives like teratoma (TE) $[5,8]$. Differentiated EC cells lose expression of the pluripotency factor OCT4, the unique embryonal transcription factor of TGCTs [9]. The expression of OCT4 and other pluripotency markers, such as SOX2 and NANOG $[10,11]$ are strictly limited to the GCNIS and undifferentiated EC cells, while absent in differentiated tissues like YST, CC and TE $[12,13]$. Therefore, OCT4 is considered 
a suitable diagnostic marker recognizing EC, seminoma and early pre-invasive GCNIS lesions [14].

Clinical diagnosis of TGCT is usually based on physical examination, testicular ultrasound and determination of serum tumor markers such as alpha-fetoprotein (AFP), human chorionic gonadotropin (hCG) and lactate dehydrogenase (LDH). Tumor staging and histology are confirmed by orchiectomy and initial treatment is designed. Most patients are diagnosed with localized disease $(>80 \%$ of SEs and $>60 \%$ of NSTs) presenting clinical stage I (CSI), localized in testicle with no evidence of distant metastases. After orchiectomy, active surveillance (AS), adjuvant chemotherapy or radiotherapy, and primary retroperitoneal lymphadenectomy management approach are usually proposed $[15,16]$. Today, AS, based on close watching of the patients and monitoring of tumor markers [17], represents an accepted alternative to radiotherapy and valid management option for patients with CSI seminoma as well as non-seminomas. This approach saves significant percentage of young patients from acute and/or chronic toxicity related to adjuvant chemotherapy. Patients with disease progression can be effectively treated with chemotherapy. For relapsing patients, salvage therapy offers excellent treatment outcomes [17].

In contrast to majority of other solid malignancies, TGCTs are highly sensitive to genotoxic chemotherapy, especially to cisplatin (CDDP). Several efficient chemotherapy regimens have been developed based on combination of CDDP with ifosfamide, etoposide, vinblastine, paclitaxel or more recently gemcitabine [18]. The use of conventional chemotherapy and surgery provides an outstanding five-year survival rate (95.3\%), even for patients diagnosed with distant metastases (73.7\%) [19-21]. However, the relapse rate for patients with seminoma is around $15-20 \%$ and for low-risk non-seminoma patients approximately $20 \%$, which may increase to up to $50 \%$ when there is lymphovascular invasion (LVI) in the primary tumor $[15,22]$. These patients experience recurrence and can develop CDDP resistance resulting in unfavorable prognosis [23]. Approximately $5 \%$ of all TGCT patients and $10-20 \%$ of patients with disseminated disease are chemoresistant to CDDP and do not achieve a durable complete remission [24, 25]. Patients who fail to achieve remission after either highdose chemotherapy or second-line salvage therapy have an extremely poor prognosis, and the vast majority eventually dies of the disease [26]. CDDP chemotherapy can trigger therapy-induced resistance, late toxicity and associates with complications and secondary side effects including infertility, cardiovascular disease, hypogonadism, chronic neurotoxicity, hearing loss, renal function impairment, pulmonary fibrosis, secondary neoplasms, and psychosocial and mental problems [27].

To identify the optimal treatment regimen for individual TGCT patients, the currently available clinical risk stratification systems are considered not sophisticated enough to truly distinguish TGCT patients with excellent and poor treatment outcomes. According to statistics and
International Germ Cell Consensus Classification (IGCCC) (1997), 55\% of patients are expected to be chemotherapyresistant and $45 \%$ of patients are expected to respond standard CDDP therapy [28]. However, such stratification is not possible upfront at the time of diagnosis.

Therefore, it is crucial to extend present knowledge of TGCT biology to develop combined clinico-biological risk stratification algorithms, improved panels of biomarkers and targets for the development of novel therapeutic agents and regimens for TGCT patients, especially for precise watching of patients during active surveillance and stratification due to risk of relapse and therapy resistance.

\section{DNA damage and response in cisplatin sensitivity}

Due to very good responsiveness to CDDP treatment even in the late phase disease [29], TGCTs serve as an excellent model system for studying the molecular mechanisms associated with chemosensitivity and resistance. However, novel diagnostic, prognostic and therapeutic approaches are not extensively applied due to the lack of novel biomarkers and druggable targets. Consequently, patients' refractories to standard chemotherapy lack the possibility to receive novel effective treatments and their prognosis is unsatisfactory [30]. Understanding mechanisms responsible for chemoresistance might disclose novel important biomarkers and potentially offer new therapeutical targets.

Chemoresistance can arise from reduced CDDP uptake, increased efflux, its inactivation by intracellular antioxidants, and increased DNA repair capacity [31]. An impressive CDDP response rates have been linked to an intrinsic hypersensitivity to DNA damaging agents, as observed in several human EC lines derived from TGCT [32] and strong correlation with the expression of OCT4, SOX2 and NANOG pluripotency factors. OCT4 expressed in embryonic stem cells controls their survival and pluripotency by cooperating with different transcription factors such as SOX2 [33]. Loss of OCT4 expression leads to CDDP resistance development [34].

In general, somatic cancer resistance to genotoxic chemotherapy associates with accumulated mutations in DNA damage response (DDR) pathways, mostly in the TP53 gene [35]. In response to chemotherapeutic drugs, the DDR is triggered by early phosphorylation-driven signaling cascades followed by a delayed response and induction of CDK (cyclin-dependent kinase) inhibitors for prolonged cell cycle arrest [36]. The cytotoxic effect of CDDP is triggered by intra- and inter-strand platinum-DNA adducts and DNA-protein crosslinks that form on DNA, such as Pt-GpG adducts [24], promoting the apoptotic pathways [37]. DDR mechanisms can repair DNA lesions via different DNA repair pathways, represented by six major classes of repair factors: (1) structure-specific nucleases, which recognize and incise specific DNA structures, (2) translesion DNA synthesis, (TLS) polymerases, error-prone polymerases that are able to tolerate DNA damage in the template DNA 
strand, (3) homologous recombination (HR), (4) mismatch repair (MMR), (5) nucleotide excision repair (NER), and (6) DNA damage response and repair pathway that is defective in patients suffering from devastating genetic disease, known as Fanconi anemia pathway (FA) [38] (Figure 1). NER represents the main defensive barrier against DNA damage [39] and a major repair system for chemo- as well as radiotherapy-induced DNA damage [40]. Therefore, the status of NER is a critical indicator of the CDDP chemotherapy outcome.

\section{NER and cisplatin resistance biomarkers}

NER represents a complex repair process carried out by seven xeroderma pigmentosum (XP) proteins (from XPA to XPG) and approximately two dozens of non-XP proteins [41]. NER works via two pathways: global genome repair (GGR) involved in injury repair for any genomic sequence, important to prevent carcinogenesis and transcription-coupled repair (TCR) [42] responsible for repair of the DNA damage of actively transcribed chains, potentially associated with tumor chemosensitivity.

Initial steps in NER involve DNA damage recognition and verification. Proteins of XPC complementation group and its accessory subunits have been identified as protein complexes involved in recognizing DNA lesions and consequent recruitment of other repair proteins [43]. XPA protein is involved in crosstalk of GGR and TCR pathways [44] and neither GGR nor TCR are initiated in the absence of XPA. It has been shown that XPA binds to the damaged duplex DNA and recruits a heterodimer endonuclease complex consisting of ERCC1 (excision repair crosscomplementation group 1) and XPF that cleaves the damaged strand contributing to the assembly of downstream NER complexes [45]. ERCC1 subunit mediates interaction of XPA with this nuclease complex, which is highly specific and essential for NER. Due to the fact that no other proteins in the cell can compensate the loss of XPA, the NER capacity can attractively be targeted via XPA. Apart from ERCC1 and XPF, XPA interacts with many other NER proteins, and is considered as a key scaffold for this repair pathway [46]. Another NER interacting partners of XPA include XPE, TFIIH (transcription factor II H), RPA (replication protein A) and PCNA (proliferating
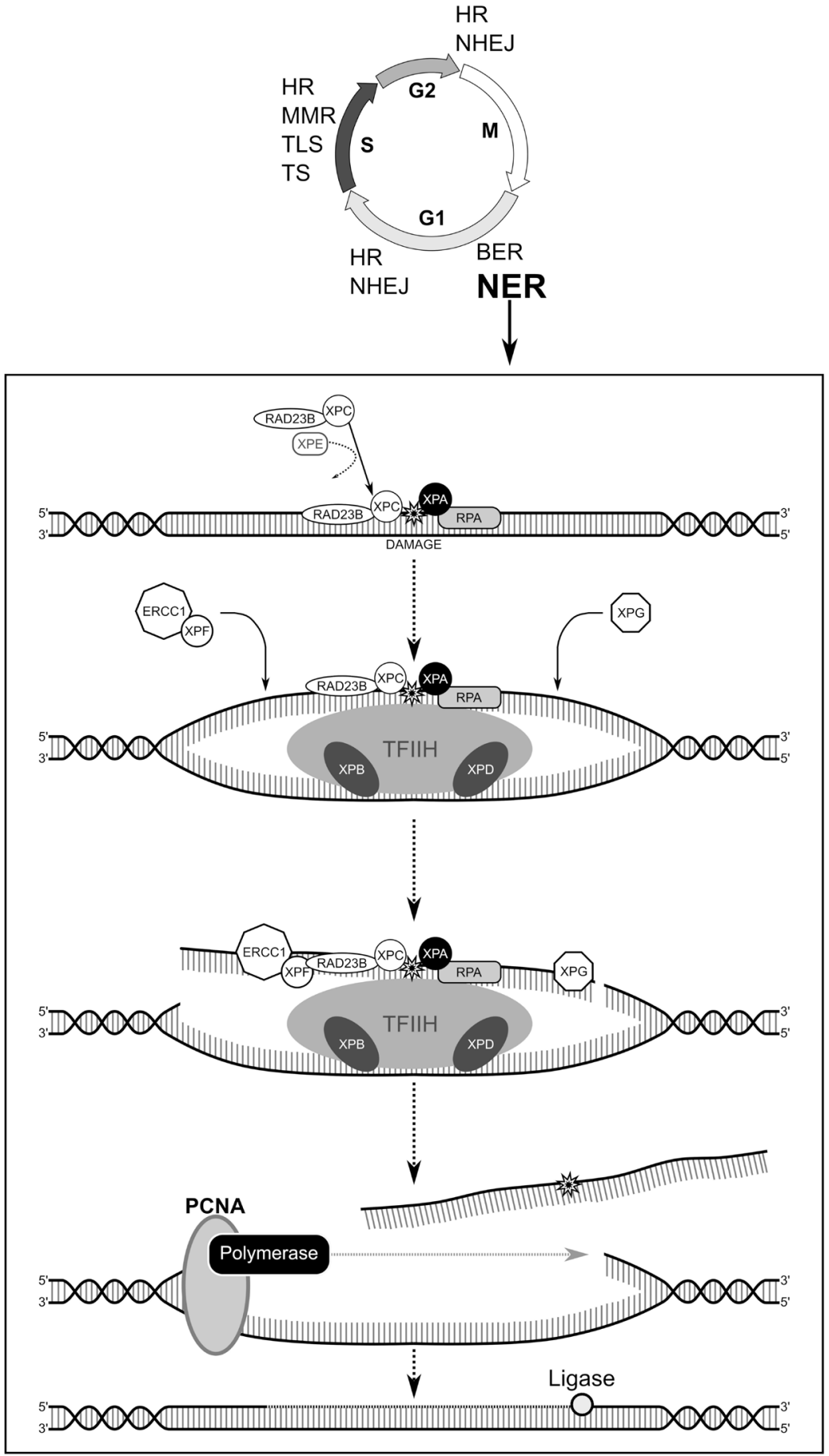

Figure 1. Activation of DNA damage repair pathways during cell cycle and schema of NER. At the top, predominant repair processes in each phase of the cell cycle are shown. Based on the type of damage during the cycle, different repair pathways are involved in DNA damage repair. NER is the main repair pathway associated with CDDP-induced DNA damage in TGCTs, and key steps of NER are illustrated below. Abbreviations: BER - base excision repair; ERCC1 - excision repair cross-complementation group 1; HR homologous recombination; MMR - mismatch repair; NER - nucleotide excision repair; NHEJ - non-homologous end joining; PCNA - proliferating cell nuclear antigen; RAD23B - excision repair protein RAD23 homolog B, RPA - replication protein A; TFIIH - transcription factor II H; TLS - translesion synthesis; TS - template switch; XP A-G - xeroderma pigmentosum group A-G. 
cellular nuclear antigen) (Figure 1). Besides the proteins directly involved in NER, XPA is also known to interact with other involved proteins, including ATR (ataxia telangiectasia and Rad3-related) kinase and PARP-1 (poly[ADP-ribose] polymerase 1). Therefore, XPA is considered one of the key rate-limiting factors of the cellular NER capacity.

TGCT cell lines have been shown to express relatively low amounts of XPA protein. This low expression was associated with CDDP hypersensitivity and reduced NER capacity [47]. On the contrary, overexpression of XPA protein has been shown in CDDP-resistant cancers $[48,49]$, where capacity of the tumor cells to repair DNA damage and avoid apoptosis is substantially increased. Additionally, high responsiveness of TGCT cells to CDDP has also been associated with increased induction of apoptosis and decreased efficiency of cell cycle arrest, probably caused by altered p53 pathway [50]. Compared to other solid tumors, majority of TGCTs express wild type p53, usually in higher amounts than normal tissue [51].

\section{Hypoxia and cisplatin resistance biomarkers}

Solid tumors are usually partly hypoxic and increased levels of hypoxia are typically associated with poor prognosis. Hypoxia in tumors promotes abnormal angiogenesis, desmoplasia and inflammation, pre-selects cancer cells with more malignant phenotype, thus promoting tumor progression and metastasis and triggers resistance to radiotherapy and chemotherapy [52]. The cellular response to the drop of oxygen concentration leads to stabilization of the hypoxiainducible transcription factor (HIF) that regulates the gene expression by binding to the hypoxia response element (HRE) in the promoter region of different genes [53].

Increased HIF protein expression is controlled through $\mathrm{PI} 3 \mathrm{~K} / \mathrm{PTEN} / \mathrm{AKT}$ and RAS/RAF/MAPK signaling [54]. HIF controls multiple tumor promoting signaling pathways including growth factor signaling, cancer cell invasion, epithelial-mesenchymal transition, metastasis, decreased apoptosis and evasion from the immune system [52]. HIF directly inhibits apoptosis by decreasing the expression of the pro-apoptotic Bcl-2 family proteins Bid and Bax [55] and induces the expression of the apoptosis inhibitor survivin [56] and anti-apoptotic proteins Bcl-2 and Bcl-xL [57]. In this way, cancer cells escape apoptosis and decrease their drug responsiveness. Hypoxia also modifies the cell surface proteins, which can shield the cells from immune system. HIF has been shown to directly upregulate programmed death-ligand 1 (PD-L1) that suppresses $\mathrm{T}$ cell and CD47 and prevents phagocytosis by macrophages [58]. Hypoxia contributes to setting a dormancy phenotype through upregulation of the main dormancy genes NR2F1, DEC2 and p27, which persist post-hypoxia helping the cancer cells to become therapy-resistant [59].

In TGCTs, HIF expression may be the master regulator of CDDP sensitivity. It stimulates glucose uptake and produc- tion of higher amounts of NADPH and glutation (GSH) [60], the two main defenders against oxidative stress. In chemosensitive TGCTs decreased HIF relates to low GSH level, reduced detoxification of CDDP and vulnerability to chemotherapy-induced oxidative stress. Increased HIF upregulates multidrug resistance 1 (MDR1) gene expression [61] and transcriptionally represses cyclin D1 that induces G1 arrest contributing to cytotoxicity and resistance $[62,63]$.

HIF binds to HRE of XPA promoter and as a key regulator of its transcription increases XPA expression that has been associated with CDDP resistance in several solid tumors $[64,65]$. Inhibition of HIF using siRNA or PX-478 protein inhibitor decreased the expression of XPA resulting in an inability to repair CDDP-induced DNA damage and enhancement of chemosensitivity of various cancer cell lines and xenografts [66].

\section{Epigenetic biomarkers}

Compared to other solid tumors TGCTs, in fact, lack relevant and reliable biomarkers. Several driver mutations in KIT, KRAS, and NRAS genes were suggested, but discovered in only a minority of patients. Due to quiet mutational landscape [67], TGCTs are considered rather polygenic. However, these tumors share unique epigenetic landscape and complex microRNA regulation. Understanding epigenetic regulation in TGCTs seems to provide novel biomarkers with significant potential for better management of this malignity.

\section{DNA methylation}

In premordial germ cells, the genome is typically highly methylated, but when developing TGCT, the genomewide methylation becomes abolished, leading to epigenetic re-programming and initiation of tumorigenesis [68]. The epigenetic profile of TGCTs is characterized by genome-wide demethylation [69]. However, seminomas and non-seminomas exert significantly different promoter methylation profiles, as well as different genetic alterations, environmental component and the familial risk, reflecting specific clinical features including CDDP resistance in TGCT patients [70-72].

Especially familial susceptibility of TGCTs has been associated with promoter methylation in identified TGCT risk genes [73]. However, aberrant promoter hypermethylation of TGCT candidate suppressor genes or tumor-related genes is not that frequent as in other human cancers [74]. While in seminomas minimal or no methylation occurs, in non-seminomas and highly differentiated non-seminomas specific gene promoters are typically hypermethylated. Testicular carcinoma in situ cells express features resembling embryonic stem cells. Genes of pluripotency transcription factors, such as POU5F1/OCT-3/4, NANOG, T1A-2, MYCL1, GDF3, LIN28-A, DPPA4, DPPA5, KIT, AP- $2 \gamma[75$, 
69] and promoters of suppressor genes including BRCA1, TP53, RASSF1A, CALCA or MGMT are usually highly methylated [76].

A tumor suppressor RASSF1A (RAS association domaincontaining protein $1 \mathrm{~A}$ ) has been found as one of the main suppressors with variable promoter methylation in TGCTs. This gene participates in cell-cycle control, microtubule stabilization, cellular adhesion, motility and apoptosis. CpG methylation of the RASSF1A has been observed in many cancers [77] and depletion of this gene has been associated with higher risk of chromosome rearrangements, accelerated mitotic progression and enhanced cellular motility [78]. The RASSF1A promoter hypermethylation has been found in both seminomas and non-seminomas being considered as the first epigenetic event of TGCT tumorigenesis [68].

DNA methylation profiles can serve as potential molecular biomarkers for prognosis prediction and treatment outcomes monitoring of TGCT patients. Using candidate gene approach Martinelli et al. [68] assessed a set of potential DNA methylation biomarkers able to accurately discriminate the clinical outcome of TGCT patients. A high frequency of MGMT (O-6-methylguanine-DNA methyltransferase) and CALCA (calcitonin related polypeptide alpha) methylation were associated with non-seminomatous tumors while CALCA methylation was associated with refractory disease. Moreover, promoter methylation of both genes has been identified as predictive for poor clinical outcome for TGCT patients [68].

Concordantly, Costa et al. [79] have reported that promoter methylation of CRIPTO/HOXA9/SCGB3A1 panel and RASSF1A best discriminate between controls and non-seminomatous or seminomas tumors, and HOXA9/ RASSF1A panel display the best discriminative performance between non-seminomas and seminomas. Significant differences in CRIPTO, MGMT and RASSF1A methylation levels were depicted between pure forms and matched mixed components of seminomas and embryonal carcinoma. HOXA9, RASSF1A and SCGB3A1 promoter methylation are significantly associated with tumor stage proving that methylation patterns may significantly contribute to identification of more clinically aggressive tumors.

\section{MicroRNAs}

The wide histological diversity of TGCTs and their individual sensitivity to chemotherapy treatments are significantly affected also by post-transcriptional regulatory network of microRNAs (miRNAs). Strictly regulated expression of miRNAs is important for various biological processes from embryonic development to cell proliferation [80], cell differentiation [81], apoptosis and metabolism [82], or tumorigenesis [83]. MiRNAs are essential for spermatogenesis and play an important role during mitotic, meiotic and post-meiotic stages of spermatogenesis [84]. TGCTs display miRNA profiles similar to embryonic stem cells [85] and their dysregulated expression relates to cancer development and progression [69].

Usually, terminally differentiated histological subtypes express high levels of the most discriminating miRNAs compared to poorly differentiated tumor subpopulations, such as seminoma or EC [86]. In seminoma, the most different expression profiles have been identified for miRNAs controlling expression of pluripotency maintaining genes OCT4, NANOG and SOX2. The expression of miR-302 cluster or key oncomiRs miR-21 and miR-155 were found strongly upregulated [86] and expression of tumor suppressor miRNAs as miR-133a, miR-145, miR-146 or miR-199a were found downregulated in TGCTs [86, 87]. In human embryonic stem cells (ESCs) miR-145 suppressed the expression of OCT4, and partially repressed the expression of SOX2 promoting their differentiation [88]. Additionally, NANOG, SOX2 and OCT4 are regulated by miR-134, miR-296 and miR-470 in ESCs [89]. Vice-versa, the pluripotency factors NANOG, OCT4 and SOX2 are able to regulate the expression of miRNA genes via direct binding to miRNA promoters, e.g. OCT4 to miR-302 cluster [90].

During the male germ cell development, the expression of tumor suppressor let-7 miRNA family increases along with miR-125a and miR-9 families [91]. These miRNAs regulate the expression of LIN28, a key controller of stem cell pluripotency implicated in the formation of testicular TE [92]. Similarly, miR-30 family [92] or miR-181 [93] have been reported to downregulate LIN28 in ESCs and cancer cells. All these miRNAs have been identified underexpressed in malignant TGCTs [94].

It is a typical feature that most germ cell tumors contain wild type p53 and overexpress miR-371, miR-372 and miR-373 (miR-371-373 cluster) [95, 86]. The miR-371-373 cluster is involved in cellular senescence induced by oncogenic stress triggering malignant transformation of the cells [86]. MiR-371-373 cluster and members of miR-302 family (miRNA-302a, miRNA-302b, miRNA-302c) have recently been proposed as markers for TGCTs [85]. These clusters are highly TGCT-specific; especially miR-371a-3p that is strongly upregulated in patients with SE, EC, YS and mixed non-seminomas. During the differentiation from EC to TE and post-orchiectomy, the expression of these miRNAs significantly declines. Similarly, miR-17-5p and miR-154 are expressed at higher levels in EC but are downregulated upon differentiation to TE [86].

Gillis and co-workers [86] found miR-301 predominantly expressed in more differentiated tissues, such as spermatocytic seminomas, YST and TE, but absent in embryonic stem cells and EC. On the contrary, miR-375 was highly expressed in TE, YST and mixed tumors, but not in SE or EC. Overexpression of these miRNAs was found to downregulate expression of histone-lysine N-methyltransferase Suv39-H1 and LATS2 (large tumor suppressor homolog 2), both involved in the Ras oncogene pathway. LATS2 deletion causes cell proliferation and oncogenic transformation, while its overexpres- 
sion was shown to prevent Ras-mediated transformation of the cells. MiR-371-373 cluster was found to directly bind to the LATS2 3'UTR to control its translation and its overexpression allowed cells to proliferate regardless of negative signals originating from $\mathrm{p} 53$ and the cell cycle inhibitor p21 [95]. MiR-373 has been identified as a cell migration and metastasis-promoting factor in breast cancer cells [96]. The same role of this miRNA can be expected in TGCT metastasis. The upregulation of miR-371-373 cluster was detected together with other miRNA molecules in several CDDPresistant germ cell tumor cell lines and is expected to play a role in inhibition of cell death and promotion of differentiation in response to CDDP [97]. Other miRNAs were found significantly upregulated in seminoma, including miR-221, miR-222, miR-372 and miR-374 [98], while others have been downregulated e.g. miR-30a, miR-34a, miR-106a, miR-136, miR-382 or miR-217 $[98,99]$.

In solid tumors, numerous miRNAs are differentially regulated by hypoxia. For example, miR-210, miR-155, miR-372, miR-373, miR-21 and miR-10b, known to have responsive element HRE in their promotor region, were found to be upregulated [100], whereas miR-20b, miR-200b or miR-199a were found downregulated [101]. On the other hand, miR-20b, miR-199a, miR-210 and miR-424, directly target HIF gene and control its expression [102]. MiR-210 is upregulated by hypoxia in most of solid tumors and targets genes involved in cell cycle regulation, cell survival, differentiation, angiogenesis, metabolism and cancer cell immune evasion [103]. This miRNA is considered a master hypoxamiR and a new biomarker of metastatic potential and chemoresistance in different solid tumors [104-106].

Downregulation of DDR genes by binding miRNAs to their 3'UTR sensitizes cancer cells to chemotherapeutic agents. For example, miR-182, miR-1255b, miR-193b, and miR-148b were found to regulate important HR proteins like BRCA1, BRCA2 and RAD51 [107]. HIF-induced miR-210 regulates RAD52, miR-96 regulates RAD51 and sensitizes cancer cells to CDDP and PARP inhibitors [108]. Similarly, in TLS, inhibition of DNA polymerase REV1 by miR-96 increases sensitivity of cancer cells to PARP inhibitors and CDDP treatment [33]. Crosby et al. [33] used HeLa, MCF-7, and mouse embryonic fibroblasts to analyze the role of miRNAs in DNA repair under hypoxic conditions. They observed upregulated miR-210 and miR-373 in hypoxic cells in HIF-dependent manner. Increased expression of miR-210 was able to suppress levels of RAD52, a key factor in HR, whereas miR-373 overexpression downregulated both, RAD52 and RAD23B, a component of the XPC/RAD23B complex involved in the NER machinery. Both miRNAs are complementary to seed sequences in 3'UTR of RAD52 and $R A D 23 B$ genes. Use of antagomirs for miR-210 and miR-373 reverted hypoxia-induced RAD52 and RAD23B downregulation [33].

Friboulet et al. [109] analyzed the role of ERCC1, a NER pathway protein involved in recognition and removal of DNA platinum adducts and in repair of stalled DNA replication forks in non-seminoma patients. ERCC1-positive tumors showed lower rate of genomic lesions than ERCC1-negatives. In ERCC1-positive cancers, downregulation of miR-375 was observed. Downregulation of miR-375 was previously described in hepatocellular carcinoma (HCC) and gastric cancer where overexpression of miR-375 was able to inhibit cell proliferation [110]. This miRNA was also predicted to target other genes involved in DNA repair, such as TP53, USP1, APEX1, TYMS, MLH3, PARP4, NTHL1, ERCC3, and $X R C C 6 B P 1$ [110]. Similarly, miR-192 is involved in DDR genes expression; it downregulates ERCC 3 and ERCC4 and its overexpression significantly inhibits cellular NER [111].

MiR-770-5p is another miRNA involved in CDDP resistance [112]. In ovarian cancer, the level of miR-770-5p expression was low in CDDP-resistant patients, but its overexpression in resistant cell lines increased sensitivity to CDDP. MiR-770-5p targets ERCC2 involved in NER and may function as an anti-oncogene promoting chemosensitivity by downregulation of ERCC2 [112].

The current clinical practice mostly requires reliable and specific tools for disease progression and treatment outcome monitoring. In this regard, miRNAs as biomarkers show a great promise. For instance, miR-371 as a biomarker for TGCT demonstrated a sensitivity of $84.7 \%$ and specificity of $99 \%$, in contrast with the serum markers AFP and hCG, that were found false negative in $50 \%$ of cases [113]. Upregulation of miR-371-373 and miR-302 clusters in both, the tissue and serum, were detected in the TGCT patients but their expression dropped significantly after orchiectomy [86, 114]. Dieckmann's [114] group further revealed the existence of a concentration gradient for these miRNAs around the tumor, being higher in the serum of the testicular vein than in peripheral serum.

Gillis et al. [115] developed a robust protocol for analyzing miR-371-373 and miR-302 clusters in serum, bringing the Target Serum miRNA test (TSmiRNA). The combination of conventional serum markers AFP, hCG and LDH evaluation and TSmiRNA provided an adequate and accurate classification of all testicular cancer samples $[116,117]$. Recently, Mego et al. [118] showed very promising translation results that provided evidence that plasma levels of miR-371a-3p correlate with several disease characteristics including sites of metastases, serum tumor markers, IGCCCG prognostic group, and favorable response to chemotherapy measured just prior to the start of therapy. This group also managed to show that prognostic value of plasma miR-371a-3p in chemotherapy naïve TGCTs patients starting first line of chemotherapy, as well as prognostic value of plasma miR-371a-3p changes during the treatment.

\section{Chronobiology}

To respect complex regulatory network, additional mechanism affecting precise control of DDR and other signaling 
pathways of the cell response (and potentially their contribution to CDDP resistance) should be considered. Such control relates to the circadian clock regulation. Approximately $40 \%$ of all proteins within the cell are subjected to circadian control [38], although in tissue specific manner [119].

Each cell is equipped with positive regulators CLOCK and BMAL1, transcriptional factors, which regulate expression of genes in mammals by interacting with E-box (CACGTG) in their promoter [120]. Heterodimer CLOCK/BMAL1 targets different repressor proteins, including negative regulators PERIOD (PER1, 2, 3) and CRYPTOCHROME (CRY1, 2), which in turn inhibit the transcriptional activity of CLOCK/ BMAL1 transcription factor [121].

Under normal physiological conditions, DDR processes are synchronized. However, the process of DDR can run independently from circadian rhythm [122]. From the broad spectrum of DNA damage responses, NER is the only one showing circadian rhythmicity. The rhythmicity of NER relates to the rhythmic expression of XPA, as observed e.g. in brain [123], skin keratinocytes [124], kidneys and liver [125]. However, rhythmic expression of XPA has not been described in testes until now [126].
The circadian clock controls the steady state level of XPA [123] by HERC2 [126] and SIRT1 [127]. The transcriptional activity of the circadian clock induces a daily rhythm of $X P A$ gene expression, whereas HERC2 functions as an E3 ubiquitin ligase for XPA degradation in a proteasome-dependent manner. The half-life of XPA protein is approximately $4 \mathrm{~h}$ in the absence of DNA damage, but much longer in the presence of DNA damage [126]. In response to DNA damage, XPA is phosphorylated by ATR kinase, which stabilizes XPA by preventing its association with HERC2 [126]. Thus, ATR activity in response to DNA damage can be utilized to a certain extent as a surrogate marker for NER activity. SIRT1, a $\mathrm{NAD}^{+}$-dependent histone deacetylase, also plays a critical role in NER pathway control.

Concerning circadian rhythms in oncological diseases, plentiful opposing, and tissue specific results can be found. Some studies report that tumors do indeed show rhythmic circadian gene expression [128], while others indicate that cancerous tissue either lacks rhythmicity or expression of clock genes is compromised $[129,130]$. Recent studies have declared absence of circadian rhythm in TGCTs, although some authors proposed that cyclic expression of clock genes

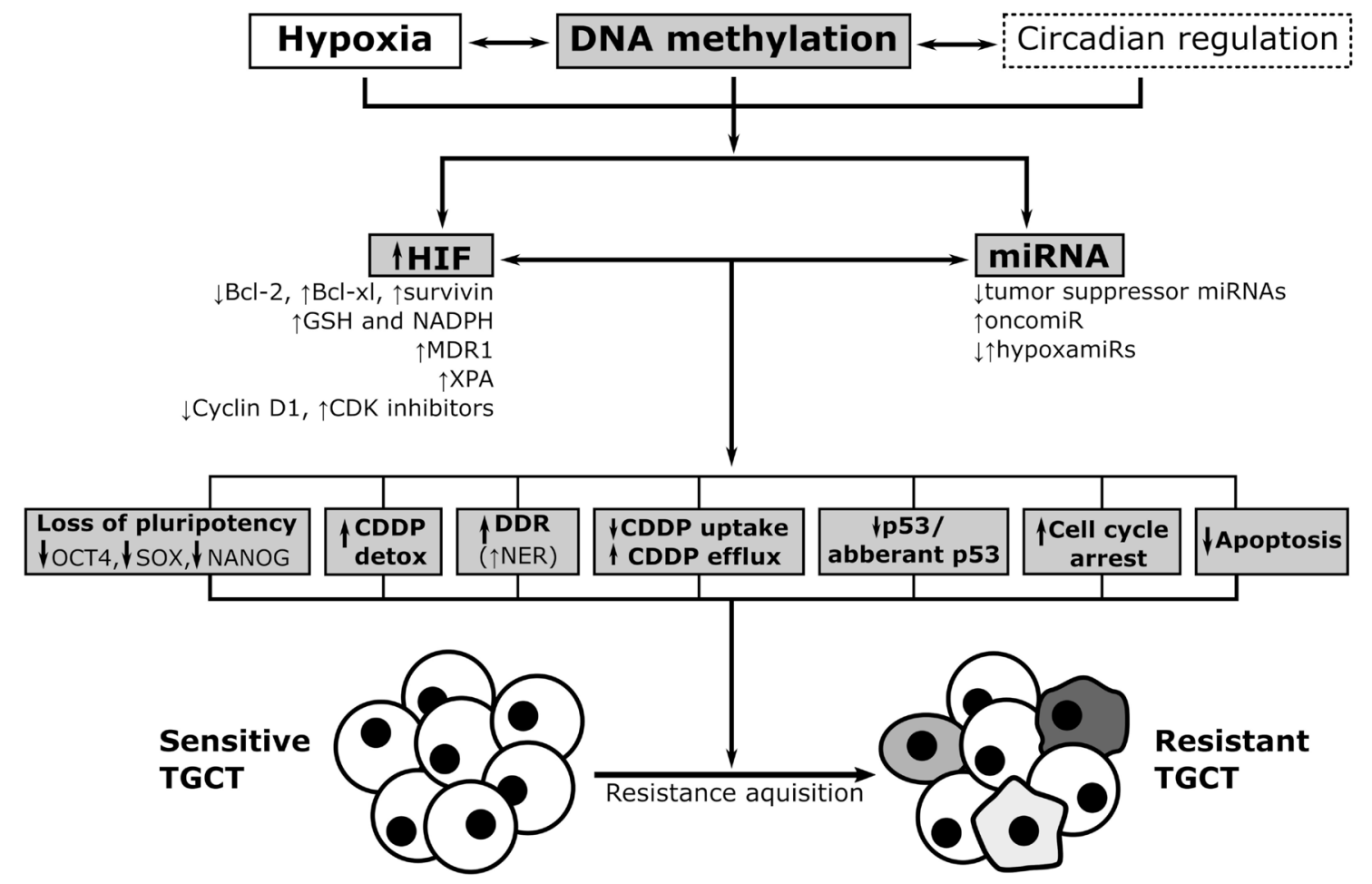

Figure 2. The crosstalk of molecular factors and signaling pathways involved in CDDP resistance in TGCTs. Cancer cell can gain chemoresistance towards CDDP via several different mechanisms: reduced cellular uptake and/or increased efflux of CDDP, increased CDDP detoxification by glutathione (GSH), regulation of the cell cycle arrest prolonging time for DNA damage response mechanisms to repair and restore CDDP-induced adducts (NER prominently), or inhibition of apoptosis. Loss of pluripotency of the cell, hypoxia - typical for solid tumors, and mutations in TP53 gene are another crucial factors contributing to chemoresistance development. All of these mechanisms are under control of transcription factors (e.g. HIF), epigenetic modulators (DNA methylation and miRNAs) and potentially, circadian regulation via clock controlled genes. To understand CDDP and other anti-cancer drug therapy resistance it is important to understand orchestration and crosstalk of multiple regulatory pathways. The key factors of these signaling pathways could represent a pool of potential novel diagnostic and prognostic biomarkers (in grey boxes). Abbreviations: CDDP - cisplatin; DDR - DNA damage response; HIF - hypoxia-inducible factor; NER - nucleotide excision repair; TGCT - testicular germ cell tumor. 
in testes is suspended due to cellular differentiation during spermatogenesis $[126,131]$.

Because TGCTs are very good model for studying mechanism of CDDP resistance and DNA damage response, understanding the absence of circadian rhythms in this tissue becomes of an increased interest. Lu et al. [132] explained post-translational circadian rhythm disruption via cancer/ testis antigen (CTA) PIWIL2, which is able to repress circadian rhythms both in tumor cells and in testes. PIWIL2 suppresses glycogen synthase kinase 3 (GSK3 $\beta$ )-induced phosphorylation to regulate the stability and activity of circadian proteins. Besides protecting BMAL1 and CLOCK from degradation, authors suggest that PIWIL2 can also bind to certain E-box sequences (PER2 and Rev-Erba promoters), to negatively regulate the transcriptional activation of main clock proteins. Michael et al. [133] supported the hypothesis of CTA disrupting the circadian rhythms in testes and in tumors. They identified the PAS domain containing protein 1 (PASD1), evolutionarily connected to CLOCK protein that can interact with the CLOCK/BMAL1 heterodimer and suppress circadian rhythmicity.

To support the complexity of this regulation, several studies point out the effect of miRNA on circadian clock. So far, miR-211 (a PERK inducible miRNA) has shown involvement in circadian clock control regulating BMAL1/CLOCK activity [134].

The presence of circadian rhythms in tumors, especially in TGCTs, needs further elucidation. Even in lack of rhythmicity, the core clock proteins still affect tumor development [135]. New information about circadian rhythms in TGCTs is needed to clarify its role and existence or the reason of its complete lack. Importantly, complex understanding of chronobiology could significantly support future clinical implications and development of chronochemotherapy regimens [136] that could potentially diminish consequences of chemoresistance in TGCT and other cancers.

\section{Conclusion}

Today, conventional clinical management of testicular germ cell tumors is largely based on the monitoring of serum tumor markers, unfortunately showing limited sensitivity and specificity [137]. Due to the limited informative value of these markers, as well as increasing requirement of individual, personalized approach to the patient, there is an urgent need of discovery of novel reliable biomarkers, mostly for diagnostics of advanced TGCT stages, precise stratification of patients prone to relapse, and prediction of chemotherapy response. An increasing number of studies provide cumulative evidence of specific epigenetic regulators as relevant oncogenic biomarkers of TGCTs [138, 139]. Deep and complex understanding of molecular mechanisms, regulatory pathways and their crosstalk involved in a therapy response remains crucial for efficient treatment management of TGCT patients, especially those that are CDDP-resistant.
Particular attention has to be paid to the role of DNA damage and repair genes, pluripotency factors, effect of hypoxia and their epigenetic and circadian controllers as they represent a pool of novel promising biomarkers or potential druggable targets (Figure 2).

Acknowledgments: This work was supported by the Grant Agency of Slovak Republic under Grants no. VEGA 2/0108/17 and 2/0053/19, by Ministry of Education, Science, Research and Sport of Slovak Republic under Grant no. MVTS 34097104 and by Slovak Research and Development Agency under Grant no. APVV-170384.

\section{References}

[1] STEVENSKON SM, LOWRANCE WT. Epidemiology and Diagnosis of Testis Cancer. Urol Clin North Am 2015; 42: 269-75. https://doi.org/10.1016/j.ucl.2015.04.001

[2] LE CORNET C, LORTET-TIEULENT J, FORMAN D, BERANGER R, FLECHON A et al. Testicular cancer incidence to rise by $25 \%$ by 2025 in Europe? Model-based predictions in 40 countries using population-based registry data. Eur J Cancer 2014; 50: 831-839. https://doi.org/10.1016/j. ejca.2013.11.035

[3] WOLDU SL, BAGRODIA A. Update on epidemiologic considerations and treatment trends in testicular cancer. Curr Opin Urol 2018; 28: 440-447. https://doi.org/10.1097/ MOU.0000000000000532

[4] LOOIJENGA LH. Human testicular (non) seminomatous germ cell tumours: the clinical implications of recent pathobiological insights. J Pathol 2009; 218: 146-162. https://doi. org/10.1002/path.2522

[5] OOSTERHUIS JW, LOOIJENGA LHJ. Testicular germ-cell tumours in a broader perspective. Nat Rev Cancer 2005; 5: 210-222. https://doi.org/10.1038/nrc1568

[6] ULBRIGHT TM, AMIN MB, BALZER B, BERNEY DM, EPSTEIN JI et al. WHO Classification of Tumours of the Urinary System and Male Genital Organs, pp 189-226. In: H. Moch, PA. Humphrey, TM. Ulbright, VE. Reuter (Eds.). WHO Classification of Tumours of the Urinary System and Male Genital Organs. Fourth edition. IARC Press, Lyon 2016, p.400. ISBN 978-9-2832-2437-2.

[7] WINTER C, ALBERS P. Testicular germ cell tumors: pathogenesis, diagnosis and treatment. Nat Rev Endocrinol 2011; 7: 43-53. https://doi.org/10.1038/nrendo.2010.196

[8] HOULDSWORTH J, KORKOLA JE, BOSL GJ, CHAGANTI RSK. Biology and genetics of adult male germ cell tumors. J Clin Oncol 2006; 24: 5512-5518. https://doi.org/10.1200/ JCO.2006.08.4285

[9] DE JONG J, STOOP H, DOHLE GR, BANGMA CH, KLIFFEN $M$ et al. Diagnostic value of OCT3/4 for pre-invasive and invasive testicular germ cell tumours. J Pathol 2005; 206: 242-249. https://doi.org/10.1002/path.1766

[10] HART AH, HARTLEY L, PARKER K, IBRAHIM M, LOOIJENGA LH et al. The pluripotency homeobox gene NANOG is expressed in human germ cell tumors. Cancer 2005; 104: 2092-2098. https://doi.org/10.1002/cncr.21435 
[11] DE JONG J, STOOP H, GILLIS AJ, VAN GURP RJ, VAN DE GEIJN GJ et al. Differential expression of SOX17 and SOX2 in germ cells and stem cells has biological and clinical implications. J Pathol 2008; 215: 21-30. https://doi.org/10.1002/ path. 2332

[12] LOOIJENGA LH, STOOP H, DE LEEUW HP, DE GOUVEIA BRAZAO CA, GILLIS AJ et al. POU5F1 (OCT3/4) identifies cells with pluripotent potential in human germ cell tumors. Cancer Res 2003; 63: 2244-2250.

[13] BERNEY DM, LOOIJENGA LHJ, IDREES M, OOSTERHUIS JW, RAJPERT-DE MEYTS E et al. Germ cell neoplasia in situ (GCNIS): evolution of the current nomenclature for testicular pre-invasive germ cell malignancy. Histopathology 2016; 69: 7-10. https://doi.org/10.1111/his.12958

[14] DE JONG J, LOOIJENGA LH. Stem cell marker OCT3/4 in tumor biology and germ cell tumor diagnostics: history and future. Crit Rev Oncog 2006; 12: 171-203. https://doi. org/10.1615/critrevoncog.v12.i3-4.10

[15] KOLLMANNSBERGER C, TANDSTAD T, BEDARD PL, COHN-CEDERMARK G, CHUNG PW et al. Patterns of relapse in patients with clinical stage I testicular cancer managed with active surveillance. J Clin Oncol 2015; 33: 51-57. https://doi.org/10.1200/JCO.2014.56.2116

[16] OLIVER RT, MASON MD, MEAD GM, VON DER MAASE $\mathrm{H}$, RUSTIN GJ et al. Radiotherapy versus single-dose carboplatin in adjuvant treatment of stage I seminoma: a randomised trial. Lancet 2005; 366: 293-300. https://doi. org/10.1016/S0140-6736(05)66984-X

[17] PECKHAM MJ, BARRETT A, HUSBAND JE, HENDRY WF. Orchidectomy alone in testicular stage I nonseminomatous germ cell tumors. Lancet 1982; 2: 678-680. https://doi. org/10.1016/s0140-6736(82)90710-3

[18] FIZAZI K, GRAVIS G, FLECHON A, GEOFFROIS L, CHEVREAU $\mathrm{C}$ et al. Combining gemcitabine, cisplatin, and ifosfamide (GIP) is active in patients with relapsed metastatic germ-cell tumors (GCT): a prospective multicenter GETUG phase II trial. Ann Oncol 2014; 25: 987-991. https:// doi.org/10.1093/annonc/mdu099

[19] Surveillance, Epidemiology, and End Results (SEER) Program. Research Data (1973-2015); National Cancer Institute, DCCPS, Surveillance Research Program: Rockville, MD, USA, 2018. https://seer.cancer.gov

[20] SHAH MN, DEVESA SS, ZHU K, MCGLYNN KA. Trends in testicular germ cell tumours by ethnic group in the United States. Int J Androl 2007; 30: 206-213. https://doi. org/10.1111/j.1365-2605.2007.00795.x

[21] STEVENSON SM, LOWRANCE WT. Epidemiology and Diagnosis of Testis Cancer. Urol Clin N Am 2015; 42: 269-275. https://doi.org/10.1016/j.ucl.2015.04.001

[22] LEUNG E, WARDE P, JEWETT M, PANZARELLA T, O'MALLEY $\mathrm{M}$ et al. Treatment burden in stage I seminoma: a comparison of surveillance and adjuvant radiation therapy. BJU Int 2013; 112:1088-1095. https://doi.org/10.1111/ bju. 12330

[23] SCHAFFRATH J, SCHMOLL HJ, VOIGT W, MULLER LP, MULLER-TIDOW $\mathrm{C}$ et al. Efficacy of targeted drugs in germ cell cancer cell lines with differential cisplatin sensitivity. PLoS One 2017; 12: e0178930. https://doi.org/10.1371/ journal.pone. 0178930
[24] KELLAND L. The resurgence of platinum-based cancer chemotherapy. Nat Rev Cancer 2007; 7: 573-584. https://doi. org/10.1038/nrc2167

[25] SHEIKINE Y, GENEGA E, MELAMED J, LEE P, REUTER $\mathrm{VE}$ et al. Molecular genetics of testicular germ cell tumors. Am J Cancer Res 2012; 2: 153-167.

[26] FANKHAUSER CD, CURIONI-FONTECEDRO A, ALLMANN V, BEYER J, TISCHLER V et al. Frequent PD-L1 expression in testicular germ cell tumors. Br J Cancer 2015; 113: 411-413. https://doi.org/10.1038/bjc.2015.244

[27] APARICIO J, TERRASA J, DURAN I, GERMA-LLUCH JR, GIRONES R et al. SEOM clinical guidelines for the management of germ cell testicular cancer. Clin Transl Oncol 2016; 18: 1187-1196. https://doi.org/10.1007/s12094-016-1566-1

[28] International Germ Cell Consensus Classification: a prognostic factor-based staging system for metastatic germ cell cancers. International germ cell cancer collaborative group. J Clin Oncol 1997; 15: 594-603. https://doi.org/10.1200/ JCO.1997.15.2.594

[29] WILLIAMS SD, STABLEIN DM, EINHORN LH, MUGGIA FM, WEISS RB et al. Immediate adjuvant chemotherapy versus observation with treatment at relapse in pathological stage II testicular cancer. N Engl J Med 1987; 317: 14331438. https://doi.org/10.1056/NEJM198712033172303

[30] CHOVANEC M, ALBANY C, MEGO M, MONTIRONI R, CIMADAMORE A et al. Emerging prognostic biomarkers in testicular germ cell tumors: looking beyond established practice. Front Oncol 2018; 8: 571. https://doi.org/10.3389/ fonc.2018.00571

[31] MARTIN LP, HAMILTON TC, SCHILDER RJ. Platinum resistance: the role of DNA repair pathways. Clin Cancer Res 2008; 14: 1291-1295. https://doi.org/10.1158/1078-0432. CCR-07-2238

[32] HUDDART RA, TITLEY J, ROBERTSON D, WILLIAMS GT, HORWICH A et al. Programmed cell death in response to chemotherapeutic agents in human germ cell tumour lines. Eur J Cancer 1995; 31A: 739-746. https://doi. org/10.1016/0959-8049(95)00047-m

[33] CROSBY ME, KULSHRESHTHA R, IVAN M, GLAZER PM. MicroRNA regulation of DNA repair gene expression in hypoxic stress. Cancer Res 2009; 69: 1221-1229. https://doi. org/10.1158/0008-5472.CAN-08-2516

[34] MUELLER T, MUELLER LP, LUETZKENDORF J, VOIGT W, SIMON H et al. Loss of Oct-3/4 Expression in embryonal carcinoma cells is associated with Induction of cisplatin resistance. Tumour Biol 2006; 27: 71-83. https://doi. org/10.1159/000092324

[35] BARTKOVA J, RAJPERT-DE MEYTS E, SKAKKEBAEK NE, LUKAS J, BARTEK J. DNA damage response in human testes and testicular germ cell tumours: biology and implications for therapy. Int J Androl 2007; 30: 282-291. https://doi. org/10.1111/j.1365-2605.2007.00772.x

[36] VIGNERON A, CHERIER J, BARRÉ B, GAMELIN E, COQUERET O. The cell cycle inhibitor p21wafl binds to the myc and cdc25A promoters upon DNA damage and induces transcriptional repression. J Biol Chem 2006; 281: 3474234750. https://doi.org/10.1074/jbc.M602492200 
[37] REBUCCI M, MICHIELS C. Molecular aspects of cancer cell resistance to chemotherapy. Biochem Pharmacol 2013; 85: 1219-1226. https://doi.org/10.1016/j.bcp.2013.02.017

[38] ZHANG J, WALTER JC. Mechanism and regulation of incisions during DNA interstrand cross-link repair. DNA Repair (Amst) 2014; 19: 135-142. https://doi.org/10.1016/j. dnarep.2014.03.018

[39] NICKOLOFF JA, JONES D, LEE SH, WILLIAMSON EA, HROMAS R. Drugging the cancers addicted to DNA repair. J Natl Cancer Inst 2017; 109. https://doi.org/10.1093/jnci/ djx059

[40] NEMEC AA, ABRIOLA L, MERKEL JS, DE STANCHINA E, DEVEAUX $M$ et al. DNA polymerase beta germline variant confers cellular response to cisplatin therapy. Mol Cancer Res 2017; 15: 269-280. https://doi.org/10.1158/1541-7786. MCR-16-0227-T

[41] COSTA RM, CHIGANCAS V, GALHARDO RDA S, CARVALHO H, MENCK CF. The eukaryotic nucleotide excision repair pathway. Biochimie 2003; 85: 1083-1099. https://doi. org/10.1016/j.biochi.2003.10.017

[42] WANG QE, HAN C, ZHANG B, SABAPATHY K, WANI AA. Nucleotide excision repair factor XPC enhances DNA damage-induced apoptosis by downregulating the antiapoptotic short isoform of caspase-2. Cancer Res 2012; 72: 666675. https://doi.org/10.1158/0008-5472.CAN-11-2774

[43] RENAUD E, MICCOLI L, ZACAL N, BIARD DS, CRAESCU CT et al. Differential contribution of XPC, RAD23A, RAD23B and CENTRIN 2 to the UV-response in human cells. DNA Repair (Amst) 2011; 10: 835-847. https://doi. org/10.1016/j.dnarep.2011.05.003

[44] LIU Y, LI Y, LU X. Regulators in the DNA damage response. Arch Biochem Biophys 2016; 594: 18-25. https://doi. org/10.1016/j.abb.2016.02.018

[45] FISCHER JM, POPP O, GEBHARD D, VEITH S, FISCHBACH A, BENEKE $S$ et al. Poly(ADP-ribose)-mediated interplay of XPA and PARP1 leads to reciprocal regulation of protein function. FEBS J 2014; 281: 3625-3641. https://doi. org/10.1111/febs.12885

[46] SUGITANI N, SIVLEY RM, PERRY KE, CAPRA JA, CHAZIN WJ. XPA: A key scaffold for human nucleotide excision repair. DNA Repair (Amst) 2016; 44: 123-135. https:// doi.org/10.1016/j.dnarep.2016.05.018

[47] WELSH C, DAY R, MCGURK C, MASTERS JR, WOOD RD et al. Reduced levels of XPA, ERCC1 and XPF DNA repair proteins in testis tumor cell lines. Int J Cancer 2004; 110: 352-361. https://doi.org/10.1002/ijc.20134

[48] WEAVER DA, CRAWFORD EL, WARNER KA, ELKHAIRI F, KHUDER SA et al. ABCC5, ERCC2, XPA and XRCC1 transcript abundance levels correlate with cisplatin chemoresistance in non-small cell lung cancer cell lines. Mol Cancer 2005; 4: 18. https://doi.org/10.1186/1476-4598-4-18

[49] STEVENS EV, RAFFELD M, ESPINA V, KRISTENSEN GB, TROPE CG et al. Expression of xero-derma pigmentosum A protein predicts improved out-come in metastatic ovarian carcinoma. Cancer 2005; 103: 2313-2319. https://doi. org/10.1002/cncr.21031
[50] SPIERINGS DC, DE VRIES EG, VELLENGA E, DE JONG S. The attractive Achilles heel of germ cell tumours: an inherent sensitivity to apoptosis-inducing stimuli. J Pathol 2003; 200: 137-148. https://doi.org/10.1002/path.1373

[51] LUTZKER SG. P53 tumour suppressor gene and germ cell neoplasia. APMIS 1998; 106: 85-89. https://doi. org/10.1111/j.1699-0463.1998.tb01323.x

[52] MONTI E, GARIBOLDI MB. HIF-1 as a target for cancer chemotherapy, chemosensitization and chemoprevention. Curr Mol Pharmacol 2011; 4: 62-77. https://doi. org/10.2174/1874467211104010062

[53] JAAKKOLA P, MOLE DR, TIAN YM, WILSON MI, GIELBERT J et al. Targeting of HIF-alpha to the von Hippel-Lindau ubiquitylation complex by O2-regulated prolyl hydroxylation. Science 2001; 292: 468-472. https://doi.org/10.1126/ science.1059796

[54] PORE N, JIANG Z, SHU HK, BERNHARD E, KAO GD et al. Akt1 activation can augment hypoxia-inducible factor-1alpha expression by increasing protein translation through a mammalian target of rapamycin-independent pathway. Mol Cancer Res 2006; 4: 471-479. https://doi.org/10.1158/15417786.MCR-05-0234

[55] ERLER JT, CAWTHORNE CJ, WILLIAMS KJ, KORITZINSKY M, WOUTERS BG et al. Hypoxia-mediated down-regulation of Bid and Bax in tumors occurs via hypoxia-inducible factor 1-dependent and -independent mechanisms and contributes to drug resistance. Mol Cell Biol 2004; 24: 2875 2889. https://doi.org/10.1128/mcb.24.7.2875-2889.2004

[56] PENG XH, KARNA P, CAO Z, JIANG BH, ZHOU M et al. Cross-talk between epidermal growth factor receptor and hypoxia-inducible factor-1alpha signal pathways increases resistance to apoptosis by up-regulating survivin gene expression. J Biol Chem 2006; 281: 25903-25914. https://doi. org/10.1074/jbc.M603414200

[57] SERMEUS A, GENIN M, MAINCENT A, FRANSOLET M, NOTTE A et al. Hypoxia-induced modulation of apoptosis and BCL-2 family proteins in different cancer cell types. PLoS One 2012; 7: e47519. https://doi.org/10.1371/journal. pone.0047519

[58] NOMAN MZ, MESSAI Y, MURET J, HASMIM M, CHOUAIB S. Crosstalk between CTC, immune system and hypoxic tumor microenvironment. Cancer Microenviron 2014; 7: 153-160. https://doi.org/10.1007/s12307-014-0157-3

[59] FLUEGEN G, AVIVAR-VALDERAS A, WANG Y, PADGEN MR, WILLIAMS JK et al. Phenotypic heterogeneity of disseminated tumour cells is preset by primary tumour hypoxic microenvironments. Nat Cell Biol 2017; 19: 120-132. https:// doi.org/10.1038/ncb3465

[60] LU H, SAMANTA D, XIANG L, ZHANG H, HU H et al. Chemotherapy triggers HIF-1-dependent glutathione synthesis and copper chelation that induces the breast cancer stem cell phenotype. Proc Natl Acad Sci U S A 2015; 112: E4600-E4609. https://doi.org/10.1073/pnas.1513433112

[61] COMERFORD KM, WALLACE TJ, KARHAUSEN J, LOUIS NA, MONTALTO MC et al. Hypoxia-inducible factor-1dependent regulation of the multidrug resistance (MDR1) gene. Cancer Res 2002; 62: 3387-3394. 
[62] WEN W, DING J, SUN W, WU K, NING B et al. Suppression of cyclin D1 by hypoxia-inducible factor-1 via direct mechanism inhibits the proliferation and 5-fluorouracil-induced apoptosis of A549 cells. Cancer Res 2010; 70: 2010-2019. https://doi.org/10.1158/0008-5472.CAN-08-4910

[63] HUANG L, AO Q, ZHANG Q, YANG X, XING H et al. Hypoxia induced paclitaxel resistance in human ovarian cancers via hypoxia-inducible factor 1alpha. J Cancer Res Clin Oncol 2010; 136: 447-456. https://doi.org/10.1007/s00432009-0675-4

[64] DABHOLKAR M, VIONNET J, BOSTICK-BRUTON F, YU JJ, REED E. Messenger RNA levels of XPAC and ERCC1 in ovarian cancer tissue correlate with response to platinumbased chemotherapy. J Clin Invest 1994; 94: 703-708. https:// doi.org/10.1172/JCI117388

[65] LIU Y, BERNAUER AM, YINGLING CM, BELINSKY SA. HIF1 $\alpha$ regulated expression of XPA contributes to cisplatin resistance in lung cancer. Carcinogenesis 2012; 33: 11871192. https://doi.org/10.1093/carcin/bgs142

[66] SCHWARTZ DL, POWIS G, THITAI-KUMAR A, HE Y, BANKSON J et al. The selective hypoxia inducible factor-1 inhibitor PX-478 provides in vivo radiosensitization through tumor stromal effects. Mol Cancer Ther 2009; 8: 947-958. https://doi.org/10.1158/1535-7163.MCT-08-0981

[67] SHEN H, SHIH J, HOLLERN DP, WANG L, BOWLBY R et al. Integrated molecular characterization of testicular germ cell tumors. Cell Rep 2018; 23: 3392-3406. https://doi. org/10.1016/j.celrep.2018.05.039

[68] MARTINELLI CMDS, LENGERT AVH, CÁRCANO FM3, SILVA ECA, BRAIT $M$ et al. MGMT and CALCA promoter methylation are associated with poor prognosis in testicular germ cell tumor patients. Oncotarget 2016; 8: 50608-50617. https://doi.org/10.18632/oncotarget.11167

[69] CHIEFFI P. An up-date on epigenetic and molecular markers in testicular germ cell tumors. Intractable Rare Dis Res 2017; 6: 319-321. https://doi.org/10.5582/irdr.2017.01070

[70] BRAIT M, MALDONADO L, BEGUM S, LOYO M, WEHLE D et al. DNA methylation profiles delineate epigenetic heterogeneity in seminoma and non-seminoma. Br J Cancer 2012; 106: 414-423. https://doi.org/10.1038/bjc.2011.468

[71] VLADUSIC T, HRASCAN R, KRUSLIN B, PECINA-SLAUS $\mathrm{N}$, PERICA $\mathrm{K}$ et al. Histological groups of human postpubertal testicular germ cell tumours harbour different genetic alterations. Anticancer Res 2014; 34: 4005-4012.

[72] KHARAZMI E, HEMMINKI K, PUKKALA E, SUNDQUIST $\mathrm{K}$, TRYGGVADOTTIR L et al. Cancer risk in relatives of testicular cancer patients by histology type and age at diagnosis: A joint study from five nordic countries. Eur Urol 2015; 68: 283-289. https://doi.org/10.1016/j.eururo.2014.12.031

[73] MIRABELLO L, KRATZ CP, SAVAGE SA, GREENE MH. Promoter methylation of candidate genes associated with familial testicular cancer. Int J Mol Epidemiol Genet 2012; 3: 213-227.

[74] COSTELLO JF, FRUHWALD MC, SMIRAGLIA DJ, RUSH LJ, ROBERTSON GP et al. Aberrant cpg-island methylation has non-random and tumour-type-specific patterns. Nat Genet 2000; 24: 132-138. https://doi.org/10.1038/72785
[75] GILLIS AJ, STOOP H, BIERMANN K, VAN GURP RJ, SWARTZMAN E et al. Expression and interdependencies of pluripotency factors LIN28, OCT3/4, NANOG and SOX2 in human testicular germ cells and tumours of the testis. Int J Androl 2011; 34: e160-174. https://doi.org/10.1111/j.13652605.2011.01148.x

[76] TABERLAY PC, JONES PA. DNA methylation and cancer. Prog Drug Res. 2011; 67: 1-23. https://doi.org/10.1007/9783-7643-8989-5_1

[77] HESSON LB, COOPER WN, LATIF F. The role of rassf1a methylation in cancer. Dis Markers 2007; 23: 73-87. https:// doi.org/10.1155/2007/291538

[78] DALLOL A, COOPER WN, AL-MULLA F, AGATHANGGELOU A, MAHER ER et al. Depletion of the ras association domain family 1 , isoform a-associated novel microtubule-associated protein, c19orf5/map1s, causes mitotic abnormalities. Cancer Res 2007; 67: 492-500. https://doi. org/10.1158/0008-5472.CAN-06-3604

[79] COSTA AL, MOREIRA-BARBOSA C, LOBO J, VILELASALGUEIRO B, CANTANTE $M$ et al. DNA methylation profiling as a tool for testicular germ cell tumors subtyping. Epigenomics 2018; 10: 1511-1523. https://doi.org/10.2217/ epi-2018-0034

[80] LEE YS, KIM HK, CHUNG S, KIM KS, DUTTA A. Depletion of human micro-RNA miR-125b reveals that it is critical for the proliferation of differentiated cells but not for the down-regulation of putative targets during differentiation. J Biol Chem 2005; 280: 16635-16641. https://doi.org/10.1074/ jbc.M412247200

[81] FOSHAY KM, GALLICANO GI. miR-17 family miRNAs are expressed during early mammalian development and regulate stem cell differentiation. Dev Biol 2009; 326: 431-443. https://doi.org/10.1016/j.ydbio.2008.11.016

[82] XU P, VERNOOY SY, GUO M, HAY BA. The Drosophila microRNA Mir-14 suppresses cell death and is required for normal fat metabolism. Curr Biol 2003; 13: 790-795. https:// doi.org/10.1016/s0960-9822(03)00250-1

[83] MANIKANDAN J, AARTHI JJ, KUMAR SD, PUSHPARAJ PN. Oncomirs: the potential role of non-coding microRNAs in understanding cancer. Bioinformation 2008; 2: 330-334. https://doi.org/10.6026/97320630002330

[84] BOUHALLIER F, ALLIOLI N, LAVIAL F, CHALMEL F, PERRARD $\mathrm{MH}$ et al. Role of miR-34c microRNA in the late steps of spermatogenesis. RNA 2010; 16: 720-731. https:// doi.org/10.1261/rna.1963810

[85] RAJPERT-DE MEYTS E, NIELSEN JE, SKAKKEBAEK NE, ALMSTRUP K. Diagnostic markers for germ cell neoplasms: from placental-like alkaline phosphatase to micro-RNAs. Folia Histochem Cytobiol 2015; 53: 177-188. https://doi. org/10.5603/FHC.a2015.0020

[86] GILLIS AJ, STOOP HJ, HERSMUS R, OOSTERHUIS JW, SUN Y et al. High-throughput microRNAome analysis in human germ cell tumours. J Pathol 2007; 213: 319-328. https://doi.org/10.1002/path.2230

[87] GU S, CHEUNG HH, LEE TL, LU G, POON WS et al. Molecular mechanisms of regulation and action of microRNA-199a in testicular germ cell tumor and glioblastomas. PLoS One 2013; 8: e83980. https://doi.org/10.1371/journal. pone. 0083980 
[88] XU YN, GUAN N, WANG ZD, SHAN ZY, SHEN JL et al. ES cell extract-induced expression of pluripotent factors in somatic cells. Anat Rec (Hoboken) 2009; 292: 1229-1234. https://doi.org/10.1002/ar.20919

[89] TAY Y, ZHANG J, THOMSON AM, LIM B, RIGOUTSOS I. MicroRNAs to Nanog, Oct4 and Sox 2 coding regions modulate embryonic stem cell differentiation. Nature 2008; 455: 1124-1128. https://doi.org/10.1038/nature07299

[90] LI HL, WEI JF, FAN LY, WANG SH, ZHU L et al. miR-302 regulates pluripotency, teratoma formation and differentiation in stem cells via an AKT1/OCT4-dependent manner. Cell Death Dis 2016; 7: e2078. https://doi.org/10.1038/cddis. 2015.383

[91] HAYASHI K, CHUVA DE SOUSA LOPES SM, KANEDA $\mathrm{M}$, TANG F, HAJKOVA $\mathrm{P}$ et al. MicroRNA biogenesis is required for mouse primordial germ cell development and spermatogenesis. PLoS One 2008; 3: e1738. https://doi. org/10.1371/journal.pone.0001738

[92] ZHONG X, LI N, LIANG S, HUANG Q, COUKOS G et al. Identification of microRNAs regulating reprogramming factor LIN28 in embryonic stem cells and cancer cells. J Biol Chem 2010; 285: 41961-41971. https://doi.org/10.1074/jbc. M110.169607

[93] LI X, ZHANG J, GAO L, MCCLELLAN S, FINAN MA et al. MiR-181 mediates cell differentiation by interrupting the Lin28 and let-7 feedback circuit. Cell Death Differ 2012; 19: 378-386. https://doi.org/10.1038/cdd.2011.127

[94] MURRAY MJ, SAINI HK, SIEGLER CA, HANNING JE, BARKER EM et al. LIN28 Expression in malignant germ cell tumors downregulates let-7 and increases oncogene levels. Cancer Res 2013; 73: 4872-4884. https://doi. org/10.1158/0008-5472.CAN-12-2085

[95] VOORHOEVE PM, LE SAGE C, SCHRIER M, GILLIS AJ, STOOP $\mathrm{H}$ et al: A genetic screen implicates miRNA-372 and miRNA-373 as oncogenes in testicular germ cell tumors. Cell 2006; 124: 1169-1181. https://doi.org/10.1016/j. cell.2006.02.037

[96] HUANG Q, GUMIREDDY K, SCHRIER M, LE SAGE C, NAGEL R et al. The microRNAs miR-373 and miR-520c promote tumour invasion and metastasis. Nat Cell Biol 2008; 10: 202-10. https://doi.org/10.1038/ncb1681

[97] PORT M, GLAESENER S, RUF C, RIECKE A, BOKEMEYER C et al. Micro-RNA expression in cisplatin resistant germ cell tumor cell lines. Mol Cancer 2011; 10: 52. https://doi. org/10.1186/1476-4598-10-52

[98] BING Z, MASTER SR, TOBIAS JW, BALDWIN DA, XU XW, TOMASZEWSKI JE. MicroRNA expression profiles of seminoma from paraffin-embedded formalin-fixed tissue. Virchows Arch 2012; 461: 663-668. https://doi.org/10.1007/ s00428-012-1325-9

[99] PARK JH, THEODORATOU E, CALIN GA, SHIN JI. From cell biology to immunology: Controlling metastatic progression of cancer via microRNA regulatory networks. Oncoimmunology 2016; 5: e1230579. https://doi.org/10.1080/21624 02X.2016.1230579

[100] LI Y, WEI Y, GUO J, CHENG Y, HE W. Interactional role of microRNAs and bHLH-PAS proteins in cancer. Int J Oncol 2015; 47: 25-34. https://doi.org/10.3892/ijo.2015.3007
[101] CHAN YC, KHANNA S, ROY S, SEN CK. miR-200b targets Ets- 1 and is down-regulated by hypoxia to induce angiogenic response of endothelial cells. J Biol Chem 2011; 286: $2047-$ 2056. https://doi.org/10.1074/jbc.M110.158790

[102] GITS CM, VAN KUIJK PF, DE RIJCK JC, MUSKENS N, JONKERS MB et al. MicroRNA response to hypoxic stress in soft tissue sarcoma cells: microRNA mediated regulation of HIF3a. BMC Cancer 2014; 14:429. https://doi. org/10.1186/1471-2407-14-429

[103] NOMAN MZ, BUART S, ROMERO P, KETARI S, JANJI B et al. Hypoxia-inducible miR-210 regulates the susceptibility of tumor cells to lysis by cytotoxic T cells. Cancer Res 2012; 72: 4629-4641. https://doi.org/10.1158/0008-5472.CAN-121383

[104] SHAO B, WANG X, ZHANG L, LI D, LIU X et al. Plasma microRNAs predict chemoresistance in patients with metastatic breast cancer. Technol Cancer Res Treat 2019; 18: 1533033819828709. https://doi. org/10.1177/1533033819828709

[105] ZHANG X, SAI B, WANG F, WANG L, WANG Y et al. Hypoxic BMSC-derived exosomal miRNAs promote metastasis of lung cancer cells via STAT3-induced EMT. Mol Cancer 2019; 18: 40. https://doi.org/10.1186/s12943-019-0959-5

[106] SILAKIT R, KITIRAT Y, THONGCHOT S, LOILOME W, TECHASEN A et al. Potential role of HIF-1-responsive microRNA210/HIF3 axis on gemcitabine resistance in cholangiocarcinoma cells PLoS One 2018; 13: e0199827. https:// doi.org/10.1371/journal.pone.0199827

[107] CHOI YE, PAN Y, PARK E, KONSTANTINOPOULOS P, DE $S$ et al. MicroRNAs down-regulate homologous recombination in the G1 phase of cycling cells to maintain genomic stability. Elife 2014; 3: e02445. https://doi.org/10.7554/ eLife.02445

[108] WANG Y, HUANG JW, CALSES P, KEMP CJ, TANIGUCHI T. MiR-96 downregulates REV1 and RAD51 to promote cellular sensitivity to cisplatin and PARP inhibition. Cancer Res 2012; 72: 4037-4046. https://doi.org/10.1158/0008-5472. CAN-12-0103

[109] FRIBOULET L, BARRIOS-GONZALES D, COMMO F, OLAUSSEN KA, VAGNER S et al. Molecular characteristics of ERCC1-negative versus ERCC1-positive tumors in resected NSCLC. Clin Cancer Res 2011; 17: 5562-5572. https:// doi.org/10.1158/1078-0432.CCR-11-0790

[110] XIE QH, HE XX, CHANG Y, SUN SZ, JIANG X et al. MiR192 inhibits nucleotide excision repair by targeting ERCC3 and ERCC4 in HepG2.2.15 cells. Biochem Biophys Res Commun 2011; 410: 440-445. https://doi.org/10.1016/j. bbrc.2011.05.153

[111] LIU AM, POON RT, LUK JM. MicroRNA-375 targets Hippo-signaling effector YAP in liver cancer and inhibits tumor properties. Biochem Biophys Res Commun 2010; 394: 623627. https://doi.org/10.1016/j.bbrc.2010.03.036

[112] ZHAO H, YU X, DING Y, ZHAO J, WANG G et al. MiR-770$5 p$ inhibits cisplatin chemoresistance in human ovarian cancer by targeting ERCC2. Oncotarget 2016; 7: 53254-53268. https://doi.org/10.18632/oncotarget.10736 
[113] SYRING I, BARTELS J, HOLDENRIEDER S, KRISTIANSEN G, MÜLLER SC et al. Circulating serum miRNA (miR-367$3 p$, miR-371a-3p, miR-372-3p and miR-373-3p) as biomarkers in patients with testicular germ cell cancer. J Urol 2015; 193: 331-337. https://doi.org/10.1016/j.juro.2014.07.010

[114] DIECKMANN KP, SPIEKERMANN M, BALKS T, FLOR I, LÖNING T Et al. MicroRNAs miR-371-3 in serum as diagnostic tools in the management of testicular germ cell tumours. Br J Cancer 2012; 107: 1754-1760. https://doi. org/10.1038/bjc.2012.469

[115] GILLIS AJ, RIJLAARSDAM MA, EINI R, DORSSERS LC, BIERMANN $\mathrm{K}$ et al. Targeted serum miRNA (TSmiR) test for diagnosis and follow-up of (testicular) germ cell cancer patients: a proof of principle. Mol Oncol 2013; 7: 1083-1092. https://doi.org/10.1016/j.molonc.2013.08.002

[116] DIECKMANN KP, RADTKE A, SPIEKERMANN M, BALKS T, MATTHIES C et al: Serum Levels of MicroRNA miR-371a-3p: A Sensitive and Specific New Biomarker for Germ Cell Tumours. Eur Urol 2017; 71: 213-220. https://doi. org/10.1016/j.eururo.2016.07.029

[117] VAN AGTHOVEN T, EIJKENBOOM WMH, LOOIJENGA LHJ. microRNA-371a-3p as informative biomarker for the follow-up of testicular germ cell cancer patients. Cell Oncol (Dordr) 2017; 40: 379-388. https://doi.org/10.1007/s13402017-0333-9

[118] MEGO M, VAN AGTHOVEN T, GRONESOVA P, CHOVANEC M, MISKOVSKA V et al. Clinical utility of plasma miR-371a-3p in germ cell tumors. J Cell Mol Med 2018; 23: 1128-1136. https://doi.org/10.1111/jcmm.14013

[119] BOZEK K, RELOGIO A, KIELBASA SM, HEINE M, DAME $\mathrm{C}$ et al. Regulation of clock-controlled genes in mammals. PLoS One 2009; 4: e4882. https://doi.org/10.1371/journal. pone.0004882

[120] REPPERT SM, WEAVER DR. Molecular analysis of mammalian circadian rhythms. Annu Rev Physiol 2001; 63: 647676. https://doi.org/10.1146/annurev.physiol.63.1.647

[121] ZHANG EE, LIU AC, HIROTA T, MIRAGLIA LJ, WELCH $\mathrm{G}$ et al. A genome-wide RNAi screen for modifiers of the circadian clock in human cells. Cell 2009; 139: 199-210. https:// doi.org/10.1016/j.cell.2009.08.031

[122] SANCAR A, LINDSEY-BOLTZ LA, KANG TH, REARDON JT, LEE JH et al. Circadian clock control of the cellular response to DNA damage. FEBS Lett 2010; 584: 2618-2625. https://doi.org/10.1016/j.febslet.2010.03.017

[123] KANG TH, REARDON JT, KEMP M, SANCAR A. Circadian oscillation of nucleotide excision repair in mammalian brain. Proc Natl Acad Sci U S A 2009; 106: 2864-2867. https://doi.org/10.1073/pnas.0812638106

[124] WANG H, VAN SPYK E, LIU Q, GEYFMAN M, SALMANS ML et al. Time-restricted feeding shifts the skin circadian clock and alters UVB-induced DNA damage. Cell Rep 2017; 20: 1061-1072. https://doi.org/10.1016/j.celrep.2017.07.022

[125] YANG Y, ADEBALI O, WU G, SELBY CP, CHIOU YY et al. Cisplatin-DNA adduct repair of transcribed genes is controlled by two circadian programs in mouse tissues. Proc Natl Acad Sci U S A 2018; 115: E4777-E4785. https://doi. org/10.1073/pnas.1804493115
[126] KANG TH, LINDSEY-BOLTZ LA, REARDON JT, SANCAR A. Circadian control of XPA and excision repair of cisplatin-DNA damage by cryptochrome and HERC2 ubiquitin ligase. Proc Natl Acad Sci U S A 2010; 107: 4890-4895. https:// doi.org/10.1073/pnas.0915085107

[127] FANG EF, SCHEIBYE-KNUDSEN M, BRACE LE, KASSAHUN H, SENGUPTA $T$ et al. Defective mitophagy in XPA via PARP-1 hyperactivation and $\mathrm{NAD}(+) / \mathrm{SIRT} 1$ reduction. Cell 2014; 157: 882-896. https://doi.org/10.1016/j. cell.2014.03.026

[128] COMAS M, KUROPATWINSKI KK, WROBEL M, TOSHKOV I, ANTOCH MP. Daily rhythms are retained both in spontaneously developed sarcomas and in xenografts grown in immunocompromised SCID mice. Chronobiol Int 2014; 31: 901-910. https://doi.org/10.3109/07420528.2 014.925469

[129] XIA HC, NIU ZF, MA H, CAO SZ, HAO SC et al. Deregulated expression of the Per1 and Per2 in human gliomas. Can J Neurol Sci 2010; 37: 365-370. https://doi.org/10.1017/ s031716710001026x

[130] SAVVIDIS C, KOUTSILIERIS M. Circadian rhythm disruption in cancer biology. Mol Med 2012; 18): 1249-1260. https://doi.org/10.2119/molmed.2012.00077

[131] CHEN H, GAO L, XIONG Y, YANG D, LI C et al. Circadian clock and steroidogenic-related gene expression profiles in mouse Leydig cells following dexamethasone stimulation. Biochem Biophys Res Commun 2017; 483: 294-300. https:// doi.org/10.1016/j.bbrc.2016.12.149

[132] LU Y, ZHENG X, HU W, BIAN S, ZHANG Z et al. Cancer/testis antigen PIWIL2 suppresses circadian rhythms by regulating the stability and activity of BMAL1 and CLOCK. Oncotarget 2017; 8: 54913-54924. https://doi.org/10.18632/ oncotarget.18973

[133] MICHAEL AK, HARVEY SL, SAMMONS PJ, ANDERSON AP, KOPALLE HM et al. Cancer/testis antigen PASD1 silences the circadian clock. Mol Cell 2015; 58: 743-754. https:// doi.org/10.1016/j.molcel.2015.03.031

[134] BU Y, YOSHIDA A, CHITNIS N, ALTMAN BJ, TAMEIRE F et al. A PERK-miR-211 axis suppresses circadian regulators and protein synthesis to promote cancer cell survival. Nat Cell Biol 2018; 20: 104-115. https://doi.org/10.1038/s41556017-0006-y

[135] SU X, CHEN D, YANG K, ZHAO Q, ZHAO D et al. The circadian clock gene PER2 plays an important role in tumor suppression through regulating tumor-associated genes in human oral squamous cell carcinoma. Oncol Rep 2017; 38: 472-480. https://doi.org/10.3892/or.2017.5653

[136] SANCAR A, LINDSEY-BOLTZ LA, GADDAMEEDHI S, SELBY CP, YE R et al. Circadian clock, cancer, and chemotherapy. Biochemistry 2015; 54: 110-123. https://doi. org/10.1021/bi5007354

[137] ALBERS P, ALBRECHT W, ALGABA F, BOKEMEYER C, COHN-CEDERMARK $G$ et al. Guide-lines on testicular cancer: 2015 update. Eur Urol 2015; 68: 1054-1068. https:// doi.org/10.1016/j.eururo.2015.07.044 
[138] MURRAY MJ, BELL E, RABY KL, RIJLAARSDAM MA, GILLIS AJ et al. A pipeline to quantify serum and cerebrospinal fluid microRNAs for diagnosis and detection of relapse in paediatric malignant germ-cell tumours. Br J Cancer 2016; 114: 151-162. https://doi.org/10.1038/bjc.2015.429
[139] LEAO R, VAN AGTHOVEN T, FIGUEIREDO A, JEWETT MAS, FADAAK K et al. Serum miRNA Predicts Viable Disease after Chemotherapy in Patients with Testicular Nonseminoma Germ Cell Tumor. J Urol 2018; 200: 126-135. https://doi.org/10.1016/j.juro.2018.02.068 